\title{
Airborne Measurements of Turbulent Heat Flux
}

\author{
By Susumu Yamamoto, Minoru Gamo and Osayuki Yokoyama \\ National Research Institute for Pollution and Resoreces, MITI, Tokyo, 115 \\ (Manuscript received 13 June 1977, in revised form 17 August 1977)
}

\begin{abstract}
The results of the turbulent heat flux obtained by airborne measurements over flat terrain and coastal areas are reported, and the structure of the atmospheric boundary layer under the condition of clear daytime is investigated.

The main results are summarized as follows:

(1) In clear daytime, turbulent heat flux $q$ over land decreases linearly with height in the lower layer and $q$ becomes zero at some height, $z_{q}$. It then has a negative peak at about a height of $1.3 z_{q}$ and its absolute value is about $20 \%$ of the surface value of $q$. The height $z_{q}$ coincides with the height of the inversion base of the potential temperature.

(2) By the analyses of the balance of turbulent energy in the atmospheric boundary layer under clear daytime conditions, we have reached the conclusion that the buoyant energy production balances the dissipation rate of the turbulent energy.

(3) Under sea-breeze conditions, the temperature variation with time can be explained by the heating due to $q$ and the cooling due to the advection of the cool sea-breeze.

(4) The height of the internal boundary layer formed by the thermal convection is investigated and the relation between $z_{q}$ and $x / U$ (where $x$ is the distance from the coastline along the wind direction and $U$ is mean wind velocity) is obtained.
\end{abstract}

\section{Introduction}

The atmospheric boundary layer has important roles not only in the heat and momentum transfer between the surface and the upper atmosphere but also in the dispersion of the air pollutants. However, the structure of the atmospheric boundary layer, particularly its turbulence characteristics, has not yet been completely clarified owing to the lack of appropriate observational means. Remedying such conditions, we developed airborne observation devices and have carried out observations of the turbulence structure in the atmospheric boundary layer over several sites.

The observed data were analysed first to obtain the quantities such as mean temperature and the dissipation rate of kinetic energy to heat which are not greatly affected by the slow fluctuations of the airplane itself. The results have already been reported in Gamo et al. (1973, 1976a, 1976b), Yamamoto et al. (1974) and Yokoyama et al. (1977).

In the next step, we directly analysed the vertical heat flux by using a correction technique developed to compensate for the fluctuations of the airplane using an inertial platform. In this paper, we investigated the relations among the heat flux, the dissipation rate of kinetic energy to heat and temperature profiles by using the observed data collected in the convective atmospheric boundary layer over relatively flat terrain.

\section{Method of observation and data processing}

\subsection{Instrumentation}

The present measurements were carried out by using a light airplane (Cessna-207). The measuring system was composed of sensor for the wind, temperature and airplane motion and a data recorder. Figure 1 shows the positions of the sensors. In Table 1, the sensors for the wind and temperature and measuring items are cited. The airplane motions, i.e., pitching, rolling and yawing angles and vertical, lateral and longitudinal accelerations are measured by the inertial platform system. The performance of this system is cited in Table 2 .

\subsection{The flight course and the method of data processing}

The flight path was chosen to be approximately parallel to the mean wind direction and the flight speed (air-speed) was $120 \mathrm{mph}(53.6 \mathrm{~m} / \mathrm{s})$. The 
Table 1. Sensors for the wind and temperature and measured quantities.

\begin{tabular}{|c|c|c|}
\hline Instrument & Measured quantity & Response \\
\hline $\begin{array}{l}\text { Hot-wire } \\
\text { anemometer }\end{array}$ & $\begin{array}{l}\text { longitudinal } \\
\text { velocity fluctuation }\end{array}$ & $\mathrm{DC}-5 \mathrm{kHz}$ \\
\hline $\begin{array}{l}\text { Sonic } \\
\quad \text { anemometer }\end{array}$ & $\begin{array}{l}\text { vertical } \\
\text { velocity fluctuation }\end{array}$ & $\mathrm{DC}-70 \mathrm{~Hz}$ \\
\hline $\begin{array}{l}\text { Sonic } \\
\text { thermometer }\end{array}$ & $\begin{array}{l}\text { temperature } \\
\text { fluctuation }\end{array}$ & $\mathrm{DC}-70 \mathrm{~Hz}$ \\
\hline $\begin{array}{l}\text { Thermister } \\
\text { thermometer }\end{array}$ & mean temperature & $\mathrm{DC}-0.3 \mathrm{~Hz}$ \\
\hline $\begin{array}{l}\text { Infrared } \\
\text { radiative } \\
\text { thermometer }\end{array}$ & $\begin{array}{l}\text { ground and sea } \\
\text { surface temperature }\end{array}$ & $\mathrm{DC}-10 \mathrm{~Hz}$ \\
\hline
\end{tabular}

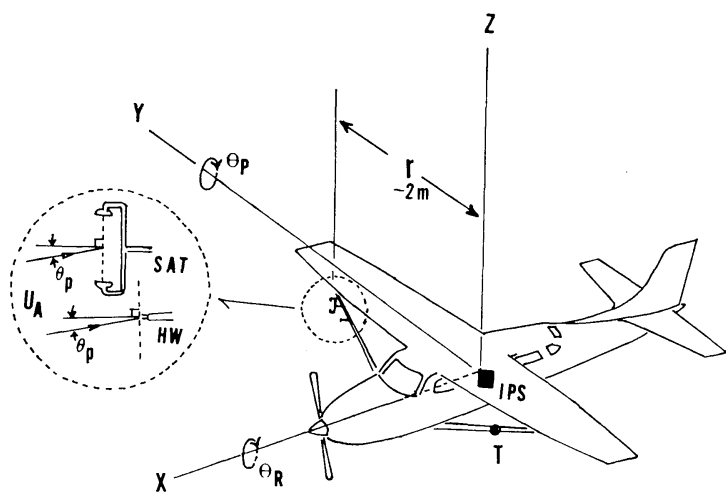

Fig. 1 Location of the various sensors; HW (Hot-wire anemometer), SAT (Sonic anemometer and thermometer), $\mathrm{T}$ (Thermister thermometer) and IPS (Inertial platform system).

flight time of one run which included 4-5 measurements at different heights was approximately one hour and the length of the flight course at each height was about $30 \mathrm{~km}$.

Data were recorded by magnetic tape recorder. The signals were passed through a low-pass filter (cut-off frequency was $2.5 \mathrm{~Hz}$ ) and digitized by an A-D converter. The sampling interval was $0.25 \mathrm{sec}$ and sampling duration was about 10 minutes. For cutting the drift of the recording level during measurement, fluctuations longer than $100 \mathrm{sec}$ were cut off by a numerical filter.
2.3 The method of correction for the airplane motion in the turbulence measurements

The method of correction for the fluctuations of the vertical velocity and temperature measured by the sonic anemometer and thermometer is described briefly.

\section{Correction of vertical velocity fluctuations}

Vertical velocity fluctuations measured by the sonic anemometer are affected by the airplane motion. The each component of the vertical motion measured by the sonic anemometer and the inertial platform is related as follows;

$$
W_{C}^{\prime}=W_{O}^{\prime}+W_{A}^{\prime}+W_{P}^{\prime}+W_{R}^{\prime},
$$

where $W_{C}^{\prime}$ : the corrected vertical fluctuation,

$W_{o^{\prime}}$ : the vertical fluctuation measured by sonic anemometer,

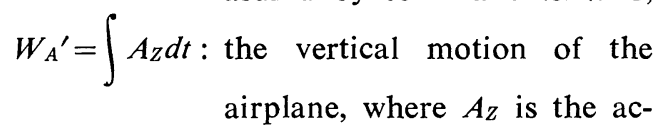
celeration detected by the inertial platform,

$W_{P}{ }^{\prime}=-U_{A} \sin \theta_{P}:$ the vertical speed caused by the pitching of the airplane, where $\theta_{P}$ is the pitching angle and $U_{A}$ is airspeed measured by the hot-wire anemometer,

$W_{R}{ }^{\prime}=-r \dot{\theta}_{R}:$ the vertical speed caused by the rolling of the airplane, where $\dot{\theta}_{R}$ is the rolling angular velocity and $r$ is the distance between sonic anemometer and gravity center of the airplane (see Figure 1).

The value of $W_{O}^{\prime}$ does not contain long period fluctuations. In other words, the airplane can be regarded as a high pass filter for the fluctuations and its cut-off frequency has been found to be approximately $0.2 \mathrm{~Hz}$ by analysing the powerspectra of $W_{O^{\prime}}$ and $W_{C}{ }^{\prime}$ (Yamamoto et al., 1975). On the other hand, in the terms $W_{A}^{\prime}$ and $W_{P}{ }^{\prime}$, the long period fluctuations are dominant, so that corrected vertical velocity, $W_{C}{ }^{\prime}$, contains the

\begin{tabular}{|c|c|c|c|c|}
\hline Measuring device & Measured quantity & Range & Accuracy & Response \\
\hline Vertical gyro & pitching and rolling angles & $\pm 40^{\circ}$ & $0.2^{\circ}$ & $60^{\circ} / \mathrm{sec}$ \\
\hline Rate gyro & yawing rate & $\pm 40^{\circ} / \mathrm{sec}$ & $0.1^{\circ} / \mathrm{sec}$ & $\mathrm{DC}-20 \mathrm{~Hz}$ \\
\hline Accelometers & $\begin{array}{l}\text { three-dimentional accelera- } \\
\text { tions }\left(A_{x}, A_{y}, A_{z}\right)\end{array}$ & $\begin{array}{l}\quad+5 \mathrm{~g} \\
\left(\mathrm{~g}=9.8 \mathrm{~m} / \mathrm{s}^{2}\right)\end{array}$ & $10^{-6} \mathrm{~g}$ & $\mathrm{DC}-250 \mathrm{~Hz}$ \\
\hline
\end{tabular}
long period fluctuations. The value of $W_{R}{ }^{\prime}$ be-

Table 2. Properties of the inertial platform system. 
comes $0.1 \mathrm{~m} / \mathrm{s}$ with taking the typical values of $\dot{\theta}_{R}$ and $r$, i.e., $\dot{\theta}_{R}=0.05 \mathrm{rad} / \mathrm{sec}$ and $r=2 \mathrm{~m}$. This value is relatively small to the other terms.

\section{Correction of temperature fluctuations}

The temperature observed by the sonic thermometer gives lower value than the true value due to the bending of sound-path at high airspeed. The difference between the observed and the true values is approximately proportional to $U_{A}^{2}$ as shown by Yamamoto et al. (1975). The proportional coefficient is determined empirically by using the output-differences of the sonic thermometer for several airspeeds between $40 \mathrm{~m} / \mathrm{s}$ and $60 \mathrm{~m} / \mathrm{s}$ at constant height (nearly constant temperature). This proportional coefficient is not affected by the air temperature in the experimental range between $15^{\circ} \mathrm{C}$ and $25^{\circ} \mathrm{C}$.

\section{Computation of turbulent heat flux}

The correction of errors due to the airplane motion is important for the calculation of turbulent heat flux. Using the corrected values $W_{C}{ }^{\prime}$ and $T_{C}{ }^{\prime}$, the turbulent vertical heat flux $q$ is calculated by

$$
q=C_{p} \rho \overline{W_{C}^{\prime} T_{C}^{\prime}},
$$

where $C_{P}$ is the specific heat at constant pressure and $\rho$ is the density of air. The over-bar in equation (2) indicates that $q$ is the mean value over the flight path (about $30 \mathrm{~km}$ ). When we calculate the horizontal distribution of $q$, the flight path is divided into several sections and $q$ is computed for each section.

The values of $q$ obtained by the airborne measurements are affected by the both variations in time and space. Nevertheless, the frozen field of turbulence can be assumed because of the airplane speed is about ten-times faster than the wind speed. Therefore, the averaging time can be approximated by $U_{A} / U$ times measuring interval, where $U$ is the mean wind speed.

In the present analysis, the fluctuations of longer period than $100 \mathrm{sec}$ (corresponds to about $5400 \mathrm{~m}$ in space) were cut off by using a numerical filter. Thus, the obtained $q$ in the analysis does not contain contribution of longer than $100 \mathrm{sec}$.

\section{Observation}

\subsection{Sites of observations}

Measurements were carried out over three sites in Japan; the southeast part of the Kanto Plain, the Kashima coastal area in Ibaraki Prefecture

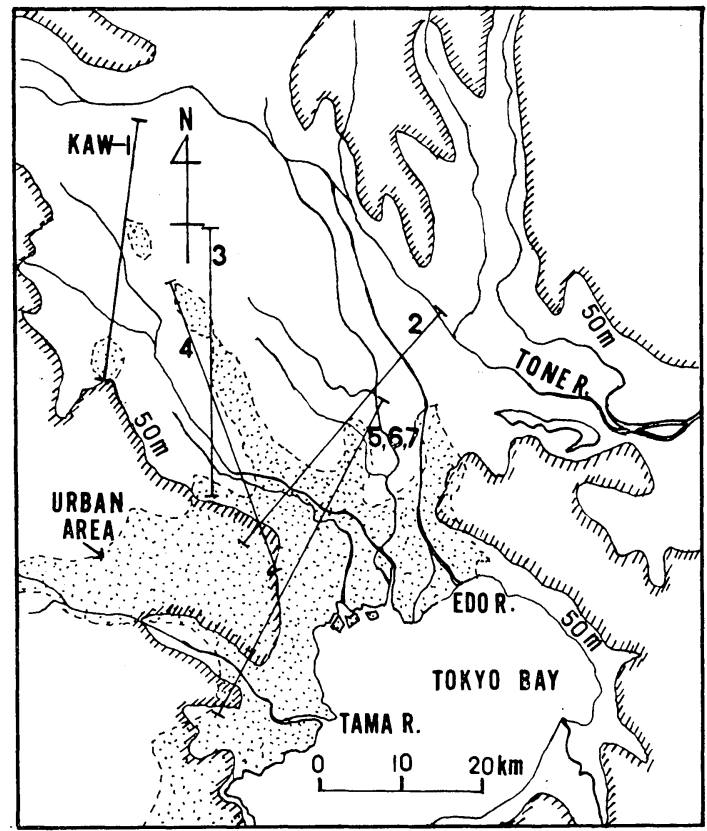

Fig. 2 Map of the Kanto Plain and flight courses.

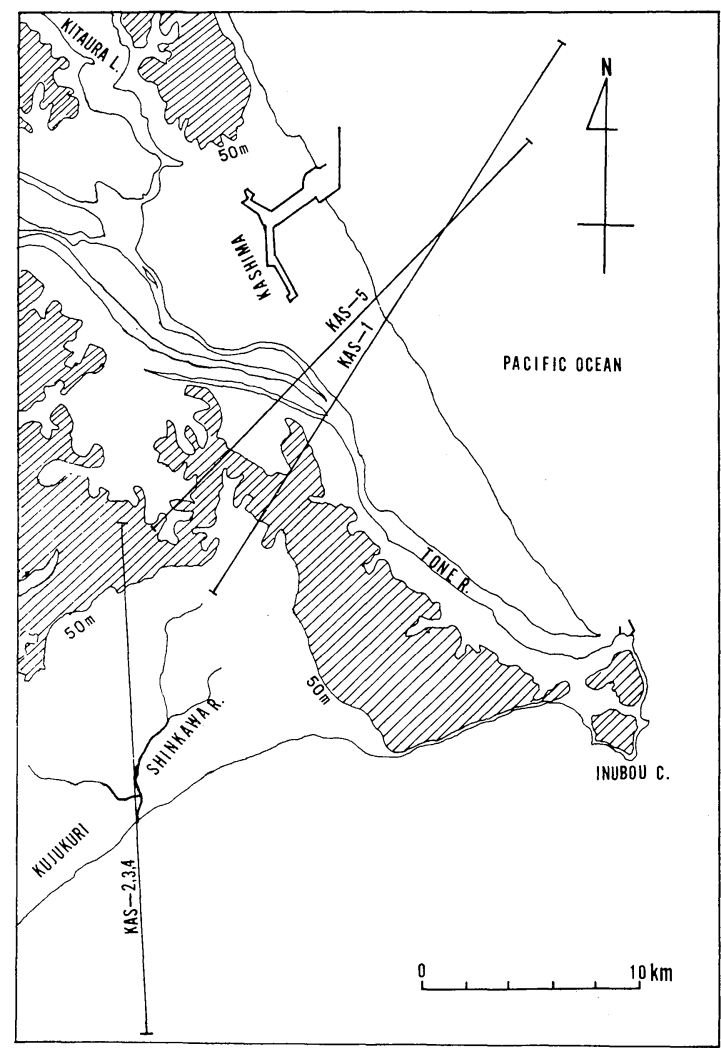

Fig. 3(a) Map of the Kashima coastal area and flight courses. 


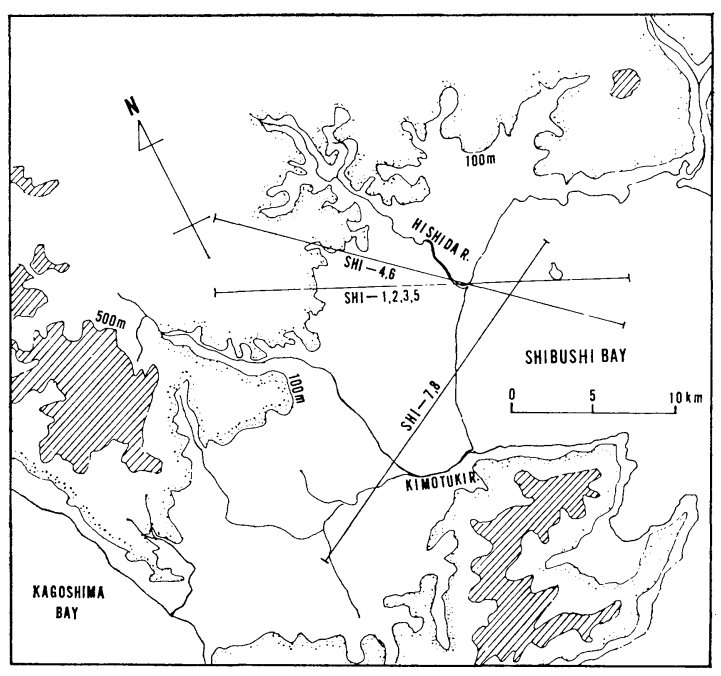

Fig. 3(b) Map of the Shibushi coastal area and flight courses.

and the Shibushi coastal area sited in the southern part of Kyushu. The maps and flight courses of these sites are shown Figures 2 and 3(a), (b).
The southern part of the Kanto Plain is nearly flat terrain and the southern part of the flight course is over an urban area as shown in Figure 2. The Kashima and Shibushi coastal areas have a comparatively simple coastline; therefore, these areas are suitable for research on the sea-breeze and internal boundary layer formed by the differences of the surface temperature and surface roughness between sea and land.

\subsection{Observational results}

The observations over the Kanto Plain were carried out on 28, 29 September, 1974 and 13, 14, 15 August, 1975 as cited in Table 3. The wind direction was nearly $S$ and its speed was about $2 \mathrm{~m} / \mathrm{s}-4 \mathrm{~m} / \mathrm{s}$, and fair-weather cumulus clouds were observed in almost all cases. Figure 4 shows vertical profiles of $q$ in KAW-1-7. The profiles of $q$ obtained in clear daytime (KAW$3,5,6$ ) are positive (upward heat flux) in the lower layer and decrease linearly with height becoming negative at some height, $z_{q}$. The values of $z_{q}$ and the base heights of the potential temperature inversion layer, $z_{i}$, are shown in Figure 4. The $q$ profiles still decrease with height above

Table 3. Observations over the Kanto Plain; Wind direction and speed indicate the representative values in the layer up to $500-700 \mathrm{~m}$ (data measured by the pilot-balloons except *-estimated from the difference between the groundspeed and the air-speed of airplane).

\begin{tabular}{rcrcllc}
\hline \multicolumn{1}{c}{ Run } & \multicolumn{1}{c}{ Date } & \multicolumn{1}{c}{ Time } & Wind Direction & Wind Speed & Cloud Species & Cloud Amount \\
\hline KAW-1 & $9 / 28,1974$ & $15: 49-16: 45$ & SE & $2-3 \mathrm{~m} / \mathrm{s}$ & $\mathrm{Cu}$ & $6 / 10$ \\
2 & $9 / 29,1974$ & $9: 53-11: 01$ & - & $1-2$ & $\mathrm{As}, \mathrm{Cu}$ & 8 \\
3 & & $12: 31-13: 26$ & $\mathrm{SE}$ & $2-3$ & $\mathrm{As}, \mathrm{Cu}$ & 4 \\
4 & $8 / 13,1975$ & $7: 05-7: 58$ & - & weak & $\mathrm{Ci}, \mathrm{Cu}, \mathrm{St}$ & 8 \\
5 & $8 / 14,1975$ & $9: 48-10: 52$ & $\mathrm{SSE}$ & 2 & - & 0 \\
6 & & $15: 50-16: 55$ & $\mathrm{SE}$ & $3-4$ & $\mathrm{Cu}$ & 1 \\
7 & $8 / 15,1975$ & $7: 08-8: 11$ & $\sim \mathrm{SSW}^{*}$ & $\sim 2^{*}$ & $\mathrm{Cu}, \mathrm{Sc}$ & 4 \\
\hline
\end{tabular}

Table 4. Same as Table 3 except over the Kashima and the Shibushi coastal areas.

\begin{tabular}{rcrccll}
\hline \multicolumn{1}{c}{ Run } & \multicolumn{1}{c}{ Date } & \multicolumn{1}{c}{ Time } & Wind Direction & Wind Speed & Cloud Species & Cloud Amount \\
\hline KAS-1 & $8 / 24,1974$ & $9: 29-10: 47$ & SSW & $5-8 \mathrm{~m} / \mathrm{s}$ & - & $0 / 10$ \\
2 & $8 / 17,1975$ & $10: 01-11: 00$ & SSE & $5-15$ & $\mathrm{Sc}, \mathrm{Ac}$ & 4 \\
3 & & $14: 28-15: 29$ & SSE & $5-10$ & $\mathrm{Sc}, \mathrm{Ac}, \mathrm{Cu}, \mathrm{Ci}$ & 8 \\
4 & $8 / 18,1975$ & $15: 28-16: 26$ & SSE & $5-10$ & $\mathrm{Sc}, \mathrm{Cu}, \mathrm{Ci}$ & 5 \\
5 & $8 / 19,1975$ & $9: 29-10: 23$ & $\sim$ SSW & $\sim 5-\sim 10^{*}$ & $\mathrm{Sc}, \mathrm{Cu}, \mathrm{Ci}$ & 4 \\
\hline SHI-1 & $9 / 9,1975$ & $9: 41-10: 52$ & ESE & $3-4 \mathrm{~m} / \mathrm{s}$ & $\mathrm{Cu}$ & $2 / 10$ \\
2 & & $12: 29-13: 36$ & ESE & $3-5$ & $\mathrm{Cu}$ & 2 \\
3 & & $15: 26-16: 12$ & ESE & $4-7$ & $\mathrm{Sc}, \mathrm{St}$ & 9 \\
4 & $9 / 10,1975$ & $9: 40-10: 51$ & E-SE & $3-6$ & - & 0 \\
5 & & $12: 31-13: 41$ & ESE & $2-5$ & - & 0 \\
6 & & $15: 30-16: 41$ & ESE & $2-4$ & - & 0 \\
7 & $9 / 11,1975$ & $9: 48-11: 00$ & WSW & $3-7$ & - & 0 \\
8 & & $12: 32-13: 41$ & SW & $5-7$ & - & 0 \\
\hline
\end{tabular}




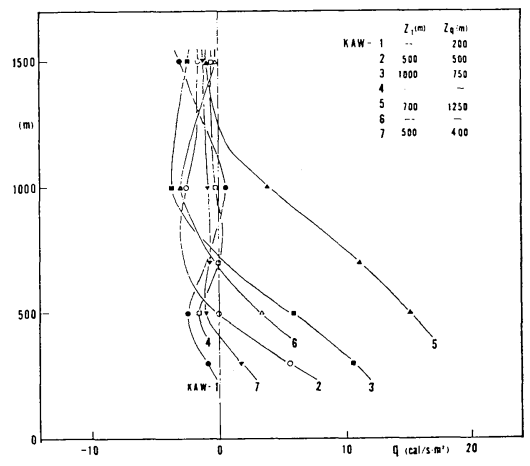

Fig. 4 The vertical profiles of $q$ obtained over the Kanto Plain.

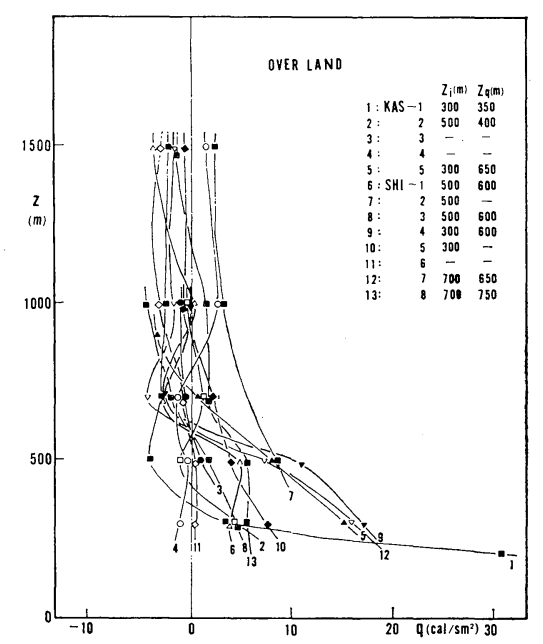

Fig. 5 The vertical profiles of $q$ obtained over land of the Kashima and Shibushi coastal areas.

$z_{q}$ and have a negative peak at some height.

In the Kashima area, the measurements were made on 24 August, 1974 and 17, 18, 19 August, 1975. Thermal convection was observed only few runs because of the cloudy and strong wind conditions with the exception of run KAS-1.

The measurements over the Shibushi area were made on 9, 10, 11 September, 1975. The weather at the time of the measurements was fair, except the afternoon of the 9 th as cited in Table 4. The sea-breeze developed during the daytime on the 9 th and 10th, and the wind directions were S-E $(3-5 \mathrm{~m} / \mathrm{s})$ at heights between the surface and $500 \mathrm{~m}$ and $W(4-5 \mathrm{~m} / \mathrm{s})$ at heights above $500 \mathrm{~m}$. Figure 5 shows the vertical profiles of $q$ obtained by the measurements over the land portions of the Kashima and Shibushi coastal areas. As in Figure 4, the values of $q$ are posi-

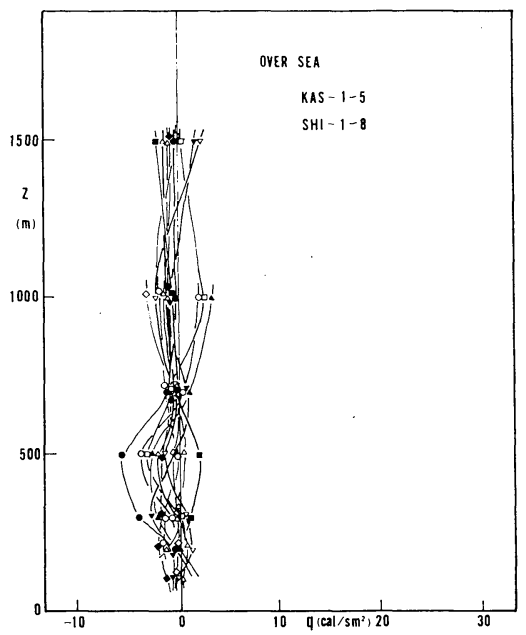

Fig. 6 The vertical profiles of $q$ obtained over sea of the Kashima and Shibushi coastal areas.

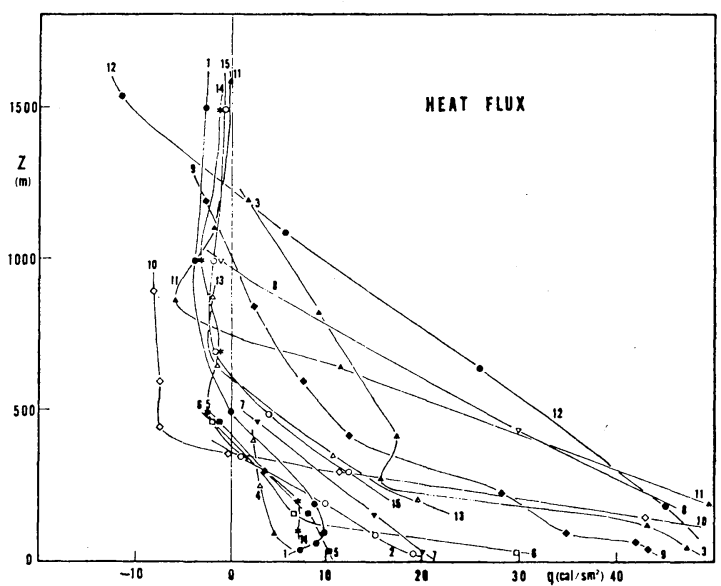

Fig. 7 The vertical profiles of $q$ measured by other researchers shown in Table 5.

tive in the lower layer and they have a negative peak in the upper layer. In Figure 6, the vertical profiles of $q$ measured by the same runs in Figure 5 , but over sea, are shown. Generally, the values of $q$ over the sea are small and negative. This result indicates that the stable surface layer is formed over the sea because of the lower seasurface temperature (refer to Appendices 2 and 3).

For reference, we reviewed the results of the airborne measurements of the turbulent heat flux in clear daytime by other researchers shown in Table 5, and vertical profiles of $q$ are graphed in Figure 7, where each number of profile curves indicates the observation number in Table 5. 
Table 5. Observations of turbulent heat flux by other reseachers.

\begin{tabular}{|c|c|c|c|}
\hline Number & Reseachers & Date & Additional information \\
\hline 1 & $\begin{array}{l}\text { Koprov and Tsvang } \\
(1965)\end{array}$ & - & $\begin{array}{l}\text { Over the steppe in summer day, developed } \\
\text { convection (mean of } 8 \text { Runs) }\end{array}$ \\
\hline 2 & \multirow{2}{*}{$\begin{array}{l}\text { Telford and Warner } \\
\text { (1964) }\end{array}$} & 12, July, 1962 & \multirow[t]{2}{*}{ Developed convection } \\
\hline 3 & & 23, July, 1962 & \\
\hline 4 & Warner $(1971)$ & 26, June-13, July, 1966 & $\begin{array}{l}\text { Over the sea }\left(16.51^{\circ} \mathrm{S}, 145.43^{\circ} \mathrm{E}\right) \text {, Wind } 5-9 \\
\mathrm{~m} / \mathrm{s} \text { (mean of } 19 \text { Runs) }\end{array}$ \\
\hline 5 & \multirow{3}{*}{$\begin{array}{l}\text { Lenschow and } \\
\text { Johnson (1968) }\end{array}$} & 31, March, 1964 & \multirow[t]{3}{*}{ Over the forest and slightly rolling terrain } \\
\hline 6 & & 8, June, 1964 & \\
\hline 7 & & 10, June, 1964 & \\
\hline 8 & Lenschow (1970) & 25, April, 1968 & $\begin{array}{l}\text { Flat treeless area, slope of the terrain }= \\
0.2 \%\end{array}$ \\
\hline 9 & Holmes (1972) & 19, July, 1970 & Over dry-land forms \\
\hline 10 & Myrup (1969) & 25, June, 1966 & $\begin{array}{l}\text { Over dry-lake in the desert, typical con- } \\
\text { vective condition }\end{array}$ \\
\hline 11 & \multirow{2}{*}{$\begin{array}{l}\text { Cattle and Weston } \\
\text { (1973) }\end{array}$} & 24, March, 1972 & \multirow{2}{*}{$\begin{array}{l}\text { Over the meadow land, gently undulating } \\
\text { region }\end{array}$} \\
\hline 12 & & 16, June, 1972 & \\
\hline 13 & Milford (1973) & 13, July, 1973 & Over the land \\
\hline 14 & $\begin{array}{l}\text { Gamo, Yamamoto } \\
\text { and Yokoyama }\end{array}$ & 23, 24, Feb., 1975 & $\begin{array}{l}\text { Over the sea, convective condition } \\
\text { (mean of } 5 \text { Runs) }\end{array}$ \\
\hline 15 & $\begin{array}{l}\text { Yamamoto, Gamo } \\
\text { and Yokoyama }\end{array}$ & refer to Tables 3 and 4 & $\begin{array}{l}\text { Over the land, convective condition } \\
\text { (mean of } 15 \text { Runs) }\end{array}$ \\
\hline
\end{tabular}

\section{Discussion of the results}

4.1 The daily variation of the vertical profiles of turbulent heat flux

The daily variation of $q$ is investigated in clear daytime. The vertical profile of $q$ and its time-variation are directly related to the tem-

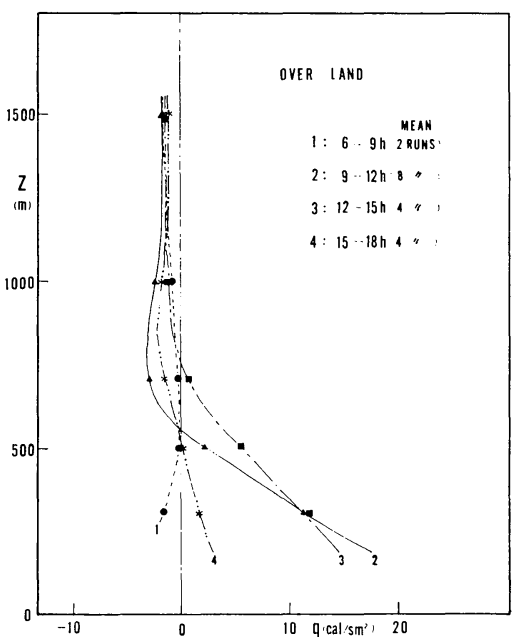

Fig. 8 Time variation of the vertical profile of $q$ over land in clear daytime. perature vertical profile and its time-variation. Figure 8 shows the vertical profiles of $q$ which are the averages of the data over land in clear daytime for each time section of 6-9 h, 9-12 h, $12-15 \mathrm{~h}$ and $15-18 \mathrm{~h}$. In the morning time section $1, q$ was small and negative in the whoie layer. This result indicates that the thermal convection did not reach up to the flight height because the heating of the ground surface by the insolation was weak and strong convection did not appear yet. And $q$ in the lower layer increases rapidly with time, and the change from profile 1 to profile 2 seem to be discontinuous. The height, $z_{q}$, moves upward with time and becomes $1000 \mathrm{~m}$ at the time section 3 and the negative peak of $q$ diminishes gradually. At the time section $4, q$ is small because the strength of the convection becomes weak with the decrease of the temperature difference between ground surface and air above.

\subsection{The vertical profile of $q$ and turbulent energy balance in convective conditions}

In the atmospheric surface layer, the heat energy is transported mainly by mechanical turbulence under moderately windy and unstable conditions. This surface layer is then thought to be in the forced convective condition. The 
height of this layer is $200 \mathrm{~m}$ at most. Above this layer, the mechanical turbulence induced by the roughness of the surface diminishes and the potential temperature gradient is small. In this layer, the heat transport by forced convection becomes negligible, and the thermal convection has a very important role in the vertical heat transport.

The depth of this upper layer may coincide with the average height at which thermal convections diminish, or the height $z_{q}$. In Figure 9, the relation between $z_{q}$ and the heights of the inversion base of potential temperature, $z_{i}$, is shown. From this figure, we may regard $z_{q}$ as approximately coinciding with $z_{i}$ in spite of the scattered data and the thermal convection are held down by the inversion layer.

Figure 10 is the plot of $q$ normalized by the exporalated value at ground level, $q_{o}$, against $z / z_{q}$. The value $q / q_{o}$ decreases linearly with $z / z_{q}$ between $z / z_{q}=0$ and 1 . The profile of $q / q_{o}$ has a negative peak $(-0.2)$ at $z / z_{q}=1.3$ which is caused by the penetrative thermal convection into the upper inversion layer. If we assume that all of the kinetic energy at $z=z_{q}$ is converted into potential energy at $z=1.3 z_{q}$, the ascent velocity of the thermal convection at $z=z_{q}$ becomes $2.9 \mathrm{~m} / \mathrm{s}$ for the values of $z_{q}=700 \mathrm{~m}$ and potential temperature gradient, $d \theta / d z=0.3^{\circ} \mathrm{C} /$ $100 \mathrm{~m}$. The values of $q / q_{o}$ are small and negative above $1.3 z_{q}$ because of the downward heat transport by the kinetic turbulence in the upper stable layer.

The above, analysis was made under the implicit assumption that the atmospheric boundary layer is in a free convective condition in clear daytime. We will investigate this assump-

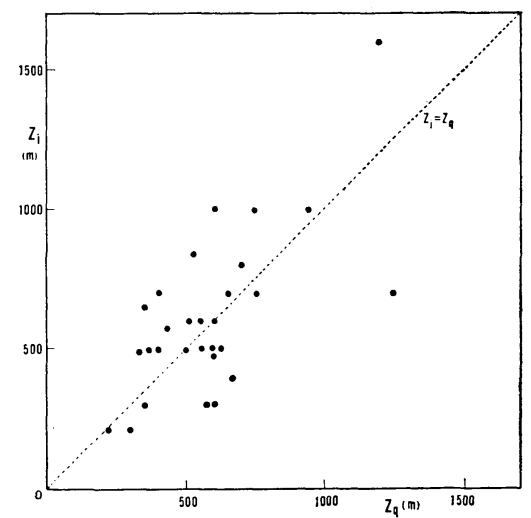

Fig. 9 Relation between $z_{q}$ and $z_{i}$ under the convective condition.

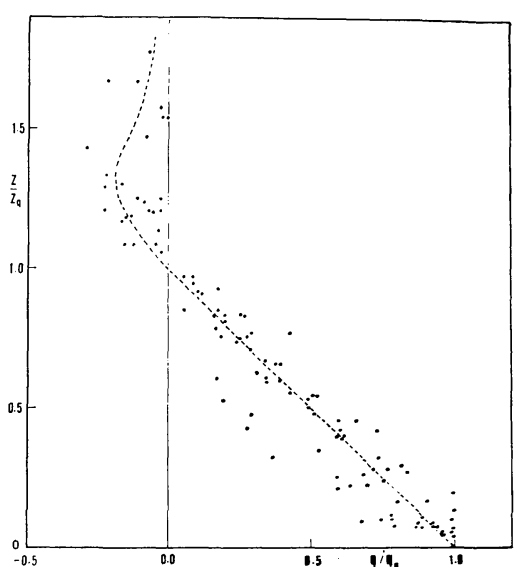

Fig. 10 The vertical profile of $q / q_{o}$ against $z / z_{q}$ under the convective condition.

tion concerning the balance of the turbulent energy. The equation of the turbulent energy for the horizontally uniform and stationary atmospheric boundary layer is

$$
\begin{aligned}
\varepsilon= & \frac{g}{T} \overline{W^{\prime} T^{\prime}}-\frac{\partial}{\partial z} \overline{\left(W^{\prime} e^{\prime}+\frac{W^{\prime} P^{\prime}}{\rho}\right)} \\
& +\frac{\tau}{\rho} \frac{\partial V}{\partial z}
\end{aligned}
$$

where $\varepsilon$ is the dissipation rate of turbulent energy, $e^{\prime}$ is the turbulent total energy, $P^{\prime}$ is the fluctuation of pressure, $\tau$ is the shear stress, and $V$ is the wind vector. The pressure fluctuation term was not measured but it may be negligible except at the top of the atmospheric boundary layer.

Figure 11 shows the relation between $\varepsilon$ and $g / T \overline{W^{\prime} T^{\prime}}$ under clear daytime conditions and in Figure 12, the variation of $g / T \overline{W^{\prime} T^{\prime}} / \varepsilon$ with height $z / z_{q}$ is shown. From these figures, it can be concluded that the equation, $\varepsilon=g / T \overline{W^{\prime} T^{\prime}}$, holds in the atmospheric boundary layer except in the surface layer and near the height of $z_{q}$ and, in this layer, free convection is predominant and the production of the turbulent energy due to the wind shear and the vertical diffusion of turbulent energy is relatively small.

\subsection{The horizontal distribution of $q$ under sea-breeze conditions}

In the former sections, only the vertical profiles of $q$ are dealt with, but the horizontal distributions of $q$ and temperature are important for the internal boundary layer formed by the differences in the roughness and temperature of the surface between the sea and land. Figure 13 


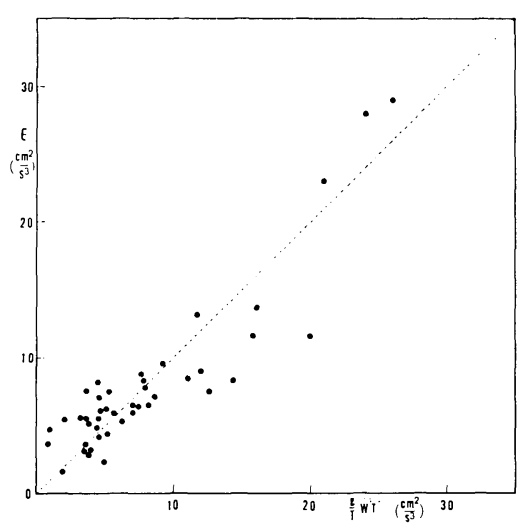

Fig. 11 Relation between $\varepsilon$ and $g / T$ $W^{\prime} T^{\prime}$ under the convective condition.

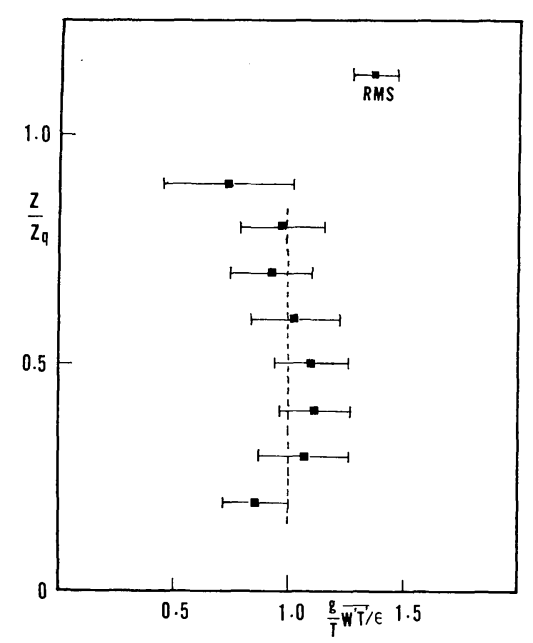

Fig. 12 The vertical profile of $g / T$ $W^{\prime} T^{\prime} / \varepsilon$ a.gainst $z / z_{q}$ under the convective condition.

shows examples of the horizontal distributions of $q$ and $T$ of the 10th of September, 1975 at the Shibushi coastal area. The wind direction was $S E$ in the lower layer and changed to $S W$ above $1000 \mathrm{~m}$ as shown in the left graph of Figure 13. In the morning (SHI-4), the values of $q$ are positive at the heights of 300 and $500 \mathrm{~m}$ over land and negative over the sea. The layer of positive $q$ extends with time and $q$ becomes positive at $z=700 \mathrm{~m}$ in the noon (SHI-5). The values of $q$ at some height and time increase with the axis extending into the inner land. Corresponding to this horizontal distribution of $q$, air temperature over land is $0.3-0.7^{\circ} \mathrm{C}$ higher than it over sea.
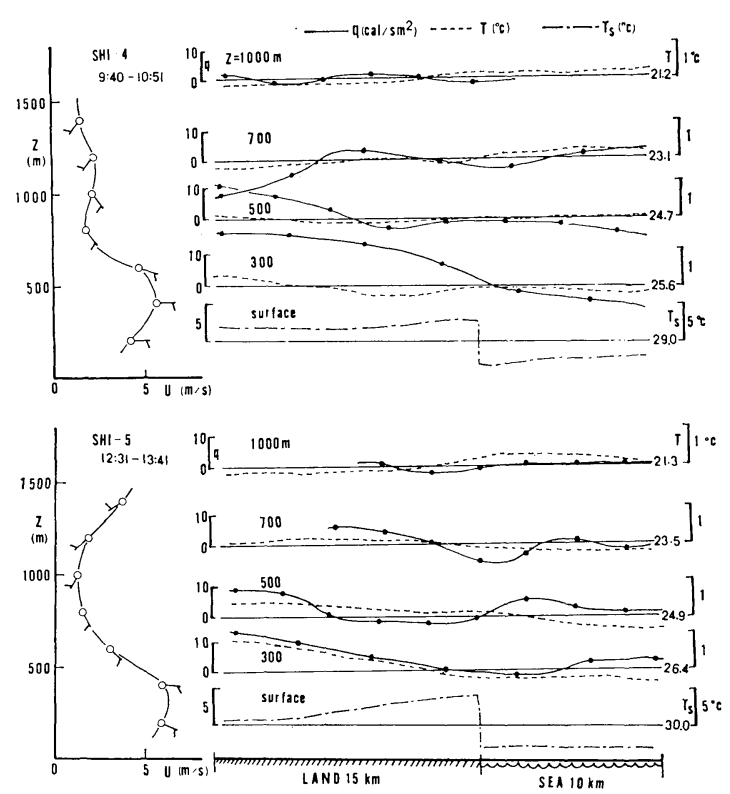

Fig. 13 An example of the horizontal distributions of heat flux and temperature on 10th September, 1975 over the Shibushi coastal area.

In these cases, the time variation of the air temperature depends on the heating by $q$ and cooling due to the cool sea-breeze. This can be described by the following relation,

$$
\frac{\partial T}{\partial t}=-U \frac{\partial T}{\partial x}-\frac{\partial}{\partial z}\left(\frac{q}{C_{p} \rho}\right),
$$

where $t$ is time, $U$ is wind and $x$ is the horizontal distance from the coastline along the wind direction. From equation (4), we can estimate the value of $q$ by using the data of the observed temperature and wind and integrating with respect to $z$. The result is shown in Figure 14. The

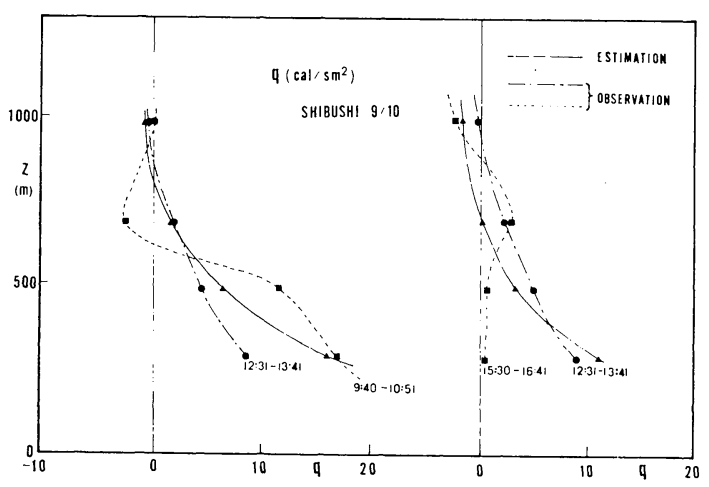

Fig. 14 An example of vertical profiles of $q$ estimated by equation (4). 


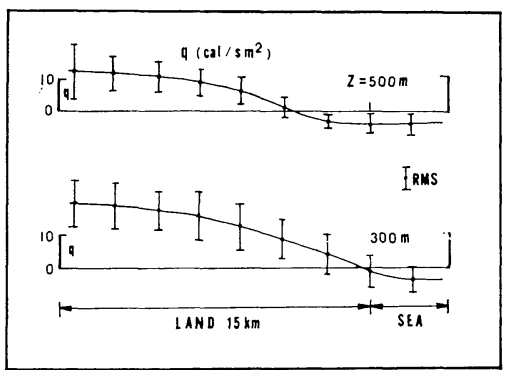

Fig. 15 Mean horizontal distributions of $q$ under sea-breeze conditions over the Shibushi coastal area.

estimated $q$ at a middle time between the two measurements approximately coincide with the observed value of $q$.

Now, we will investigate the relation between the depth of the internal boundary layer and the distance from the coastline along the wind direction. Figure 15 shows the mean horizontal distributions of $q$ obtained from the data at the heights of 300 and $500 \mathrm{~m}$ under sea-breeze conditions on the 9th and 10th of September, 1975 at the Shibushi coastal area. The heights at which $q$ becomes zero, $z_{q}$, are determined by linear interpolation from the horizontal distribution of $q$ at 300 and $500 \mathrm{~m}$ for every two kilometers along $x$. The height $z_{q}$ can be considered to be the depth of the internal boundary layer formed by termal convection.

Assuming the invariance of $q_{o}$ and potential temperature gradient in the upper layer with time and neglecting the temperature gap of the upper part of the internal boundary layer, the height $z_{q}$ is proportional to the square root of the time, $t$ (e.g., Panofsky, 1973). Substituting $x / U$ to $t$,

$$
z_{q} \propto\left(\frac{x}{U}\right)^{0.5}
$$

is obtained, where $U$ is the wind speed at $z=$

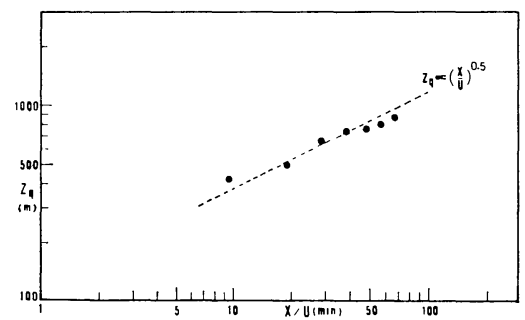

Fig. 16 Relation between $z_{q}$ and $x / U$ under sea-breeze conditions over the Shibushi coastal area.
$100 \mathrm{~m}$

Figure 16 is a graph of the relation between $z_{q}$ and $x / U$ obtained by the measurements. The dotted line in Figure 16 indicates the relation $z_{q} \propto(x / U)^{0.5}$. Near the coastline, $z_{q}$ increases suddenly; but the starting point of the internal boundary layer can not be clearly determined because of insufficient data.

\section{Conclusions}

The results of the turbulent heat flux obtained by the airborne measurements and the structure of the atmospheric boundary layer are investigated.

In clear daytime, $q$ over the land decreases approximately linearly with height in the lower layer and $q$ becomes zero at some height $z_{q}$. It has a negative peak at about height of $1.3 z_{q}$ and its absolute value is about $20 \%$ of $q_{o}$. The height $z_{q}$ coincides with the height of the inversion base of the potential temperature.

We analysed the balance of the turbulent energy in the atmospheric boundary layer under clear daytime conditions and reached the conclusion that $g / T \overline{W^{\prime} T^{\prime}}$ was balanced with $\varepsilon$ in the atmospheric boundary layer except in the surface layer and near the height $z_{q}$.

By the analysis of the horizontal distributions of $q$ and $T$, the temperature variation with time can be explained by the heating due to $q$ and cooling due to the advection of the cool seabreeze. We determined the height of the internal boundary layer formed by the thermal convections using the horizontal distributions of $q$ and obtained the result that $z_{q}$ is approximately proportional to $(x / U)^{0.5}$.

\section{Acknowledgements}

The present authors express their sincere thanks to Prof. Y. Mitsuta of Kyoto University for his helpful suggestions about the correction method for airplane motions on the turbulence measurements.

Thanks are due to pilots and mechanics of Toho Aeroservice Co. who were involved in our airborne measurements, Mr. Y. Kobori and his staff of Kaijo Denki Co., Dr. Y. Ogawa and Mrs. P. Ogawa who reviewed the manuscript, and to all members in NRIPR, particularly to Messrs. T. Mizuno and H. Yoshikado for their cooperation and helpful discussion. 
Appendix 1. Data obtained by the KAW-1-7 Runs; Wind: pilot-balloon measurement, $T$ : air temperature, $q$ : turbulent heat flux, $\varepsilon$ : energy dissipation rate, $T_{s}$ : land $(\mathrm{L})$ and sea $(\mathrm{S})$ surface temperature, $Z_{i}$ : the base height of the potential temperature inversion layer, $Z_{q}$ : the height of $q=0$.

\begin{tabular}{|c|c|c|c|c|c|c|c|c|}
\hline Run & $\begin{array}{l}\text { Height } \\
\text { (m) }\end{array}$ & $\begin{array}{l}\text { Wind } \\
(\mathrm{m} / \mathrm{s})\end{array}$ & $\begin{array}{c}T \\
\left({ }^{\circ} \mathrm{C}\right)\end{array}$ & $\underset{\left(\mathrm{cal} / \mathrm{sm}^{2}\right)}{q}$ & $\left(\mathrm{~m}^{2} / \mathrm{s}^{3} \times 10^{-4}\right)$ & $\begin{array}{c}T_{s} \\
\left({ }^{\circ} \mathrm{C}\right)\end{array}$ & $\begin{array}{c}Z_{i}, \\
(\mathrm{~m})\end{array}$ & $\begin{array}{c}Z_{q} \\
(\mathrm{~m})\end{array}$ \\
\hline \multirow[t]{4}{*}{ KAW-1 } & 1,500 & $2 \mathrm{WNW}$ & 16.4 & -3.1 & 0.14 & \multicolumn{3}{|c|}{$T_{s}=--$} \\
\hline & 1,000 & $1 \mathrm{E}$ & 19.9 & 0.3 & 0.85 & \multirow{2}{*}{\multicolumn{3}{|c|}{$\begin{array}{l}Z_{i}=-- \\
Z_{a}=200\end{array}$}} \\
\hline & 500 & $3 \mathrm{SE}$ & 21.2 & -2.5 & 0.51 & \multirow{2}{*}{\multicolumn{3}{|c|}{$Z_{q}=200$}} \\
\hline & 300 & $2 \mathrm{SE}$ & $23 \cdot 1$ & -0.9 & 0.57 & & & \\
\hline \multirow[t]{5}{*}{ KAW-2 } & 1,500 & $1.5 \mathrm{~S}$ & 11.1 & -1.6 & 0.31 & \multirow{5}{*}{\multicolumn{3}{|c|}{$\begin{array}{l}T_{s}=31.2 \\
Z_{i}=500 \\
Z_{q}=500\end{array}$}} \\
\hline & 1,000 & $2 \mathrm{SE}$ & 13.2 & -2.5 & 0.46 & & & \\
\hline & 700 & 1.5ESE & 15.4 & - & 4.2 & & & \\
\hline & 500 & $1.5 \mathrm{E}$ & 16.7 & 0.0 & 12.9 & & & \\
\hline & 300 & $2 \mathrm{NNE}$ & 19.0 & 5.6 & 16.5 & & & \\
\hline \multirow[t]{4}{*}{ KAW-3 } & 1,500 & $3.5 \mathrm{SW}$ & 12.3 & -2.5 & 0.16 & \multirow{4}{*}{\multicolumn{3}{|c|}{$\begin{array}{l}T_{s}=29.5 \\
Z_{i}=1,000 \\
Z_{q}=750\end{array}$}} \\
\hline & 1,000 & 3 SE & 15.2 & -3.7 & 0.33 & & & \\
\hline & 500 & 3 ESE & 20.7 & 5.9 & 5.2 & & & \\
\hline & 300 & 2.5ESE & 23.2 & 10.6 & 8.5 & & & \\
\hline \multirow[t]{4}{*}{ KAW-4 } & 1,500 & - & 18.9 & -0.6 & 0.08 & \multirow{4}{*}{\multicolumn{3}{|c|}{$\begin{array}{l}T_{s}=24.6 \\
Z_{i}=-- \\
Z_{q}=--\end{array}$}} \\
\hline & 1,000 & - & 20.4 & -0.3 & 0.01 & & & \\
\hline & 700 & - & 21.5 & 0.0 & 0.04 & & & \\
\hline & 500 & - & 22.6 & -1.6 & 0.33 & & & \\
\hline \multirow[t]{4}{*}{ KAW-5 } & 1,500 & 2 SSE & 19.2 & -0.6 & 0.05 & \multirow{4}{*}{\multicolumn{3}{|c|}{$\begin{array}{l}T_{s}=39.0 \\
Z_{i}=700 \\
Z_{q}=1,250\end{array}$}} \\
\hline & 700 & 2 SSE & 23.2 & 11.2 & 13.2 & & & \\
\hline & 500 & 2 SSE & 25.4 & 15.2 & 13.7 & & & \\
\hline & 300 & 1 SSE & 25.8 & - & - & & & \\
\hline \multirow[t]{3}{*}{ KAW-6 } & 1,500 & $1 E$ & 19.7 & -0.6 & 0.05 & \multirow{3}{*}{\multicolumn{3}{|c|}{$\begin{array}{l}T_{s}=34.5 \\
Z_{i}=-- \\
Z_{q}=--\end{array}$}} \\
\hline & 1,000 & $2.5 \mathrm{SE}$ & 22.4 & -3.4 & 1.6 & & & \\
\hline & 500 & $4 \mathrm{SE}$ & 26.2 & 3.4 & 3.7 & & & \\
\hline \multirow[t]{5}{*}{ KAW-7 } & 1,500 & - & 18.1 & -1.6 & 0.42 & \multirow{5}{*}{\multicolumn{2}{|c|}{$\begin{aligned} T_{s} & =29.0 \\
Z_{i} & =500 \\
Z_{q} & =400\end{aligned}$}} & \\
\hline & 1,000 & - & 20.6 & -0.9 & 0.05 & & & \\
\hline & 700 & - & 22.9 & -0.6 & 0.05 & & & \\
\hline & 500 & - & 23.5 & -1.2 & 0.90 & & & \\
\hline & 300 & - & 24.1 & 1.6 & 0.48 & & & \\
\hline
\end{tabular}


Appendix 2. Data obtained by the KAS-1-5 Runs.

\begin{tabular}{|c|c|c|c|c|c|c|c|c|c|c|}
\hline \multirow{2}{*}{ Run } & \multirow{2}{*}{$\underset{\text { (m) }}{\text { Height }}$} & \multirow{2}{*}{$\begin{array}{l}\text { Wind } \\
(\mathrm{m} / \mathrm{s})\end{array}$} & \multicolumn{2}{|c|}{$T\left({ }^{\circ} \mathrm{C}\right)$} & \multicolumn{2}{|c|}{$q\left(\mathrm{cal} / \mathrm{sm}^{2}\right)$} & \multicolumn{2}{|c|}{$\varepsilon\left(\mathrm{m}^{2} / \mathrm{s}^{3} \times 10^{-4}\right)$} & \multirow{2}{*}{$\begin{array}{rr}T_{s}, & Z_{i}, \\
\left({ }^{\circ} \mathrm{C}\right) & (\mathrm{m})\end{array}$} & \multirow{2}{*}{$\begin{array}{c}Z_{q} \\
(\mathrm{~m})\end{array}$} \\
\hline & & & $\mathrm{L}$ & $\mathrm{S}$ & $\mathrm{L}$ & $\mathrm{S}$ & $\mathrm{L}$ & $\mathrm{S}$ & & \\
\hline \multirow[t]{6}{*}{ KAS-1 } & 1,500 & $8 \mathrm{SW}$ & 19.9 & 19.9 & -2.5 & 0.9 & 0.01 & 0.01 & \multicolumn{2}{|l|}{$T_{s}(\mathrm{~L})=34.3$} \\
\hline & 1,000 & $9 \mathrm{SW}$ & 21.8 & 22.1 & -2.5 & -2.2 & 0.05 & 0.19 & \multicolumn{2}{|l|}{$T_{s}(\mathrm{~S})=24.6$} \\
\hline & 700 & $7 \mathrm{SW}$ & 22.8 & 22.9 & -1.2 & -3.1 & 0.45 & 2.1 & \multicolumn{2}{|l|}{$Z_{i}=300$} \\
\hline & 500 & $5 \mathrm{SSW}$ & 24.3 & 24.2 & -5.0 & -0.3 & 4.8 & 0.68 & \multicolumn{2}{|l|}{$Z_{q}=350$} \\
\hline & 300 & $6 \mathrm{~S}$ & 24.5 & 24.0 & 3.4 & -2.2 & 7.6 & 1.2 & & \\
\hline & 200 & $5 \mathrm{SSW}$ & - & - & 32.6 & -1.6 & 11.4 & 0.70 & & \\
\hline \multirow[t]{7}{*}{ KAS-2 } & 1,500 & - & 18.6 & 18.3 & - & -0.6 & - & 0.02 & \multicolumn{2}{|l|}{$T_{s}(\mathrm{~L})=34.0$} \\
\hline & 1,000 & $6 \mathrm{~S}$ & 21.2 & 21.0 & -0.3 & - & 0.05 & - & \multicolumn{2}{|l|}{$T_{s}(\mathrm{~S})=23.3$} \\
\hline & 700 & $17 \mathrm{SSE}$ & 23.1 & 23.2 & 1.2 & -0.9 & 0.09 & 0.03 & $Z_{i}=500$ & \\
\hline & 500 & $15 \mathrm{SSE}$ & 24.4 & 24.5 & -1.6 & -1.6 & 0.02 & 0.15 & \multicolumn{2}{|l|}{$Z_{q}=400$} \\
\hline & 300 & $10 \mathrm{SSE}$ & 26.4 & 26.5 & 4.3 & - & 4.3 & 0.02 & & \\
\hline & 200 & $7 \mathrm{SSE}$ & - & 27.3 & - & -2.2 & - & - & & \\
\hline & 100 & $6 \mathrm{SSE}$ & - & 27.8 & - & -0.9 & - & 0.01 & & \\
\hline \multirow[t]{6}{*}{ KAS-3 } & 1,000 & 9 SSE & 21.6 & 21.9 & 0.0 & -3.1 & 0.02 & 0.07 & \multicolumn{2}{|l|}{$T_{s}(\mathrm{~L})=35.3$} \\
\hline & 700 & 9 SSE & 23.6 & 23.9 & -0.6 & -0.9 & 0.04 & 0.02 & \multirow{2}{*}{\multicolumn{2}{|c|}{$\begin{array}{l}T_{s}(\mathrm{~S})=23.9 \\
Z_{i}=-\end{array}$}} \\
\hline & 500 & $8 \mathrm{SSE}$ & 24.9 & 24.9 & 0.9 & -0.6 & 0.10 & 0.03 & & \\
\hline & 300 & $6 \mathrm{~S}$ & 26.2 & 26.4 & - & 0.0 & - & 0.03 & \multicolumn{2}{|l|}{$Z_{q}=-$} \\
\hline & 200 & $6 \mathrm{SSE}$ & - & 27.4 & - & -0.3 & - & 0.03 & & \\
\hline & 100 & 5.5SSE & - & 27.8 & - & -0.6 & - & 0.01 & & \\
\hline \multirow[t]{8}{*}{ KAS-4 } & 1,500 & - & 17.8 & 18.0 & 1.2 & -0.6 & 0.07 & 0.02 & \multirow{2}{*}{\multicolumn{2}{|c|}{$\begin{aligned} T_{s}(\mathrm{~L}) & =31.5 \\
T_{s}(\mathrm{~S}) & =23.2\end{aligned}$}} \\
\hline & 1,000 & $9 \mathrm{SSE}$ & 22.2 & 21.5 & 2.5 & -0.9 & 0.01 & 0.13 & & \\
\hline & 700 & $10 \mathrm{~S}$ & 24.1 & 23.8 & -0.3 & 0.0 & 0.03 & 0.09 & \multicolumn{2}{|l|}{$Z_{i}=-$} \\
\hline & 500 & $7 \mathrm{SSE}$ & 24.9 & 24.9 & -0.6 & - & 0.01 & 0.05 & \multicolumn{2}{|l|}{$Z_{q}=-$} \\
\hline & 300 & 6 SSE & 26.9 & 27.0 & -1.2 & -1.2 & 0.50 & 0.01 & & \\
\hline & 200 & $8 \mathrm{SSE}$ & - & 27.8 & - & 0.6 & - & 0.04 & & \\
\hline & 100 & $10 \mathrm{SSE}$ & - & 28.3 & - & 0.0 & - & 0.03 & & \\
\hline & 50 & - & - & 28.3 & - & -0.3 & - & 0.04 & & \\
\hline \multirow[t]{7}{*}{ KAS-5 } & 1,500 & - & 20.9 & 20.1 & - & - & - & 0.05 & $T_{s}(\mathrm{~L})=35.4$ & \\
\hline & 900 & - & 22.9 & 22.2 & -4.3 & - & 0.65 & 1.1 & $T_{s}(\mathrm{~S})=22.3$ & \\
\hline & 500 & - & 24.4 & 24.4 & 8.1 & -5.3 & 7.3 & 2.1 & $Z_{i}=300$ & \\
\hline & 300 & - & 26.1 & 26.6 & 14.9 & -6.8 & 11.7 & 0.48 & $Z_{q}=650$ & \\
\hline & 200 & - & 27.4 & 27.2 & 44.1 & -6.2 & 8.6 & 2.3 & & \\
\hline & 150 & - & - & 27.9 & - & -5.9 & - & 0.6 & & \\
\hline & 50 & - & - & 29.1 & - & -2.5 & - & 1.0 & & \\
\hline
\end{tabular}


Appendix 3. Data obtained by the SHI-1-8 Runs.

\begin{tabular}{|c|c|c|c|c|c|c|c|c|c|c|}
\hline \multirow{2}{*}{ Run } & \multirow{2}{*}{$\underset{(\mathrm{m})}{\text { Height }}$} & \multirow{2}{*}{$\begin{array}{l}\text { Wind } \\
(\mathrm{m} / \mathrm{s})\end{array}$} & \multicolumn{2}{|c|}{$T\left({ }^{\circ} \mathrm{C}\right)$} & \multicolumn{2}{|c|}{$q\left(\mathrm{cal} / \mathrm{sm}^{2}\right)$} & \multicolumn{2}{|c|}{$\varepsilon\left(\mathrm{m}^{2} / \mathrm{s}^{3} \times 10^{-4}\right)$} & \multirow{2}{*}{\multicolumn{2}{|c|}{$\begin{array}{ccc}T_{s}, & Z_{i}, & Z_{q} \\
\left({ }^{\circ} \mathrm{C}\right) & (\mathrm{m}) & (\mathrm{m})\end{array}$}} \\
\hline & & & $\mathbf{L}$ & $\mathrm{S}$ & $\mathrm{L}$ & $\mathrm{S}$ & $\mathrm{L}$ & $\mathrm{S}$ & & \\
\hline \multirow[t]{6}{*}{ SHI-1 } & 1,500 & 4 WNW & 17.8 & 17.5 & -1.9 & - & 0.12 & 0.05 & \multirow{6}{*}{$\begin{array}{l}T_{s}(\mathrm{~L})=- \\
T_{s}(\mathrm{~S})=- \\
Z_{i}=500 \\
Z_{q}=600\end{array}$} & \\
\hline & 1,000 & $3.5 \mathrm{SW}$ & 20.5 & 20.6 & 0.3 & - & 0.09 & - & & \\
\hline & 700 & $1 \mathrm{SW}$ & 22.7 & 22.9 & -0.9 & -1.2 & 1.1 & 0.13 & & \\
\hline & 500 & 3 ESE & 24.2 & 24.1 & 5.0 & -6.2 & 7.5 & 0.33 & & \\
\hline & 300 & $3 \mathrm{E}$ & 25.7 & 25.5 & 3.7 & -3.7 & 3.3 & 0.78 & & \\
\hline & 200 & $2.5 \mathrm{ESE}$ & - & 26.7 & - & 0.0 & - & 1.0 & & \\
\hline \multirow[t]{5}{*}{ SHI-2 } & 1,500 & $4.5 \mathrm{NW}$ & 18.5 & 18.8 & 2.8 & - & 0.16 & 0.40 & \multirow{5}{*}{$\begin{array}{l}T_{s}(\mathrm{~L})=32.1 \\
T_{s}(\mathrm{~S})=27.3 \\
Z_{i}=500 \\
Z_{q}=-\end{array}$} & \\
\hline & 1,000 & $2 \mathrm{WNW}$ & 21.5 & 21.2 & 2.5 & 1.9 & 0.28 & - & & \\
\hline & 500 & $3 \mathrm{ESE}$ & 24.9 & 24.9 & 8.7 & -2.2 & 9.6 & 1.1 & & \\
\hline & 300 & 5 ESE & 26.6 & 26.4 & 1.9 & 0.0 & 5.5 & 1.8 & & \\
\hline & 200 & 5.5ESE & - & 27.2 & - & - & - & 1.5 & & \\
\hline \multirow[t]{5}{*}{ SHI-3 } & 1,000 & $2 \mathrm{SW}$ & 21.0 & 20.8 & -4.0 & - & 0.22 & - & \multirow{5}{*}{\multicolumn{2}{|c|}{$\begin{array}{l}T_{s}(\mathrm{~L})=28.0 \\
T_{s}(\mathrm{~S})=27.3 \\
Z_{i}=500 \\
Z_{q}=600\end{array}$}} \\
\hline & 700 & $1 \mathrm{SSE}$ & 23.4 & 23.1 & -1.6 & 0.6 & 0.03 & 0.46 & & \\
\hline & 500 & $6.5 \mathrm{SE}$ & 24.6 & 24.5 & 1.9 & -1.9 & 1.7 & 0.27 & & \\
\hline & 300 & $7 \mathrm{ESE}$ & 26.1 & 26.1 & 4.7 & -1.9 & 2.4 & 1.4 & & \\
\hline & 200 & $6 \mathrm{ESE}$ & - & 27.1 & - & -2.5 & - & 0.98 & & \\
\hline \multirow[t]{6}{*}{ SHI-4 } & 1,500 & $3 \mathrm{SW}$ & 18.1 & 18.3 & - & -1.6 & 0.12 & 0.12 & \multirow{6}{*}{\multicolumn{2}{|c|}{$\begin{array}{l}T_{s}(\mathrm{~L})=31.3 \\
T_{s}(\mathrm{~S})=27.1 \\
Z_{i}=300 \\
Z_{q}=600\end{array}$}} \\
\hline & 1,000 & $2 \mathrm{SSW}$ & 21.1 & 21.3 & 0.0 & 0.0 & 0.10 & 0.03 & & \\
\hline & 700 & $3 \mathrm{SE}$ & 23.0 & 23.2 & -3.1 & 0.0 & 0.25 & 0.12 & & \\
\hline & 500 & $6 \mathrm{ESE}$ & 24.7 & 24.7 & 10.9 & -2.8 & 4.2 & 0.02 & & \\
\hline & 300 & 5 ESE & 25.7 & 25.5 & 16.8 & -0.6 & 2.8 & 0.01 & & \\
\hline & 200 & $4 \mathrm{E}$ & - & 26.4 & - & -0.6 & - & 0.10 & & \\
\hline \multirow[t]{6}{*}{ SHI-5 } & 1,500 & $4 \mathrm{WSW}$ & 17.7 & 17.2 & -1.6 & -1.9 & 0.05 & 0.12 & \multirow{6}{*}{\multicolumn{2}{|c|}{$\begin{array}{l}T_{s}(\mathrm{~L})=32.3 \\
T_{s}(\mathrm{~S})=27.2 \\
Z_{i}=300 \\
Z_{q}=-\end{array}$}} \\
\hline & 1,000 & $1 \mathrm{SSW}$ & 21.3 & 21.4 & -0.9 & - & 0.07 & - & & \\
\hline & 700 & $2 \mathrm{SE}$ & 23.5 & 23.4 & -2.5 & -0.3 & 0.41 & 0.73 & & \\
\hline & 500 & $1.5 \mathrm{SE}$ & 25.0 & 24.6 & 4.6 & 2.2 & 4.8 & 0.71 & & \\
\hline & 300 & 6 ESE & 26.4 & 25.9 & 7.5 & 0.9 & 8.4 & 0.77 & & \\
\hline & 100 & $4 \mathrm{ESE}$ & - & 27.8 & - & - & - & - & & \\
\hline \multirow[t]{6}{*}{ SHI-6 } & 1,500 & $3.5 \mathrm{WNW}$ & 18.2 & 18.3 & -3.4 & -0.3 & 0.10 & 0.07 & \multirow{6}{*}{\multicolumn{2}{|c|}{$\begin{array}{l}T_{s}(\mathrm{~L})=28.5 \\
T_{s}(\mathrm{~S})=27.3 \\
Z_{i}=- \\
Z_{q}=-\end{array}$}} \\
\hline & 1,000 & $2 \mathrm{SW}$ & 21.2 & 21.4 & -2.8 & 2.2 & 0.14 & 0.07 & & \\
\hline & 700 & $2 \mathrm{SSE}$ & 24.2 & 24.3 & -0.3 & -0.6 & 0.39 & 0.62 & & \\
\hline & 500 & $2 \mathrm{ESE}$ & 25.7 & 26.1 & 0.3 & -3.4 & 1.5 & 0.21 & & \\
\hline & 300 & 3.5ESE & 27.0 & 26.7 & - & -0.6 & - & 0.39 & & \\
\hline & 200 & $4 \mathrm{SE}$ & - & 27.8 & - & 0.0 & - & 0.35 & & \\
\hline SHI-7 & 1,500 & - & 19.5 & 19.4 & -0.9 & 0.9 & 0.09 & 0.36 & $T_{s}(\mathrm{~L})=33.1$ & \\
\hline & 1,000 & $8 \mathrm{SW}$ & 21.3 & 21.0 & 0.0 & - & 1.3 & - & $T_{s}(\mathrm{~S})=27.3$ & \\
\hline & 700 & $6 \mathrm{WSW}$ & 22.8 & 23.1 & -4.0 & 0.0 & 2.9 & 1.8 & $Z_{i}=700$ & \\
\hline & 500 & $6 \mathrm{WSW}$ & 24.8 & 24.8 & 7.8 & - & 6.4 & - & $Z_{q}=650$ & \\
\hline & 300 & 4 WSW & 26.7 & 26.2 & 15.5 & -2.8 & 5.8 & 2.3 & & \\
\hline & 200 & 2.5SSW & - & 27.6 & - & -0.6 & - & 10.8 & & \\
\hline & 100 & $2 \mathrm{SSW}$ & - & 28.4 & - & -0.6 & - & 4.8 & & \\
\hline SHI-8 & 1,500 & 6 WSW & 21.1 & 20.9 & -2.2 & 1.6 & 0.08 & 0.40 & $T_{s}(\mathrm{~L})=36.5$ & \\
\hline & 700 & $6.5 \mathrm{SW}$ & 24.2 & 24.4 & 0.9 & -1.9 & 4.7 & 0.87 & $T_{s}(\mathrm{~S})=27.3$ & \\
\hline & 500 & $6 \mathrm{SW}$ & 26.3 & 26.2 & 3.4 & - & 5.5 & - & $Z_{i}=700$ & \\
\hline & 300 & $4.5 \mathrm{SW}$ & 28.3 & 27.8 & 5.3 & 0.0 & 5.9 & 1.5 & $Z_{q}=750$ & \\
\hline & 200 & 6 WSW & - & 28.6 & - & 1.6 & - & 4.8 & & \\
\hline & 100 & $4.5 \mathrm{WSW}$ & - & 29.2 & - & -0.3 & - & 2.7 & & \\
\hline
\end{tabular}




\section{References}

Cattle, H., and K. J. Weston, 1973: The structure and development of the boundary layer over land. Quart. J. Roy. Meteor. Soc., 99, 767-768.

Gamo, M., S. Yamamoto and O. Yokoyama, 1973: An airborne measurement of the structure of the atmospheric boundary layer. Kogai, 8, 156-170.

- O. Yokoyama, S. Yamamoto and Y. Mitsuta, 1976a: Structure of the atmospheric boundary layer derived from airborne measurements of the energy dissipation rate $\varepsilon$. J. Meteor. Soc. Japan, 54, 241-258.

S. Yamamoto, O. Yokoyama and $\mathrm{H}$. Yoshikado, 1976b: Airborne measurement of the internal boundary layer above the coastal area. Kogai, 11, 247-261.

Holmes, R. M., 1972: An airborne instrument system for atmospheric boundary-layer research. Bound. Layer Meteor., 3, 59-76.

Koprov, B. M., and L. R. Tsvang, 1965: Direct measurements of turbulent heat flux from an airplane. Izv. Atmos. Oceanic Phys., 1, 371-374 (AGU translation).

Lenschow, D. H., and W. B. Johnson, Jr., 1968: Concurrent airplane and balloon measurements of atmospheric boundary-layer structure over a forest. J. Applied Meteor., 7, 79-89. 1970: Airplane measurements of planetary boundary layer structure. J. Applied Meteor., 9, 874-884.

Milford, J. R., 1973: Measurements of convective heat fiuxes using a powered glider. Quart. J. Roy. Meteor. Soc., 89, 768-771.

Myrup, L. O., 1969: Turbulence spectra in stable and convective layers in the free atmosphere. Tellus, 21, 342-354.

Panofsky, H. A., 1973: "Tower micrometeorology"; Workshop on micrometeorology. The American Meteorological Society, 151-176.

Telford, J. W., and J. Warner, 1964: Fluxes of heat and vapor in the lower atmosphere derived from aircraft observations. J. Atmos. Sci., 21, 539 548.

Warner, J., 1971: Observations of the eddy fluxed of heat and vapour over the sea. Quart. J. Roy. Meteor. Soc., 97, 540-547.

Yamamoto, S., M. Gamo and O. Yokoyama, 1974: Some features of the structure of the planetary boundary layer. Kogai, 9, 16-23.

method of correction of the errors in the airborne measurements of atmospheric boundary layer. Kogai, 10, 260-270.

Yokoyama, O., M. Gamo and S. Yamamoto, 1977: On the turbulence quantities in the atmospheric mixing layer. J. Meteor. Soc. Japan, 55, 182192 .

\title{
飛行機による乱流熱輸送量の観測について
}

\author{
山本晋, 蒲生稔, 横山長之 \\ 通産省公害資源研究所
}

平坦地および海岸地帯上空での飛行機観測による乱流熱輸送量 $q$ の測定結果について述べ，それにもとづいて主に 晴天時日中の大気境界層の状態について考察した。

ここで得られた主要な結論は

(1)晴天時日中の $q$ は下層で高度 $z$ とともに直線的に減少し, ある高度 $z_{q}$ で $q=0$ となりさらに上層の $z=1.3 z_{q}$ 近 傍で負のピークをもつ。そのピーク值の絶対值は地上での值の $20 \%$ 程度である。また $z_{q}$ と温位の逆転層底部高度 ziはほほ致する。

(2)晴天時日中では接地気層と大気境界層上端部をのぞく高度において乱流運動エネルギーのバランスは粘性による 運動エネルギー消散項と浮力からの運動エネルギー生成項の間に成立している。

(3)海風発生時の $q$ と気温の水平分布および時間変化について考察し, 気温の時間変化は $q$ による加熱と海風による 冷気の流入による冷却により表わされることがわかった。また熱対流により形成される内部境界層の厚さを示す $z_{q}$ と 吹流時間 $(x / U)$ の間の関係を調べ， $z_{q}$ は $(x / U)^{0.5}$ に比例するといら結果を得た。 